\title{
Mitigation of Biotic and Abiotic Stresses in Mat Type Seedlings Raised for Mechanical Rice Transplanter
}

\author{
Tangina Aktar Tamanna ${ }^{1}$, Md. Anwar Hossen², Muhammad Rashed Al Mamun ${ }^{3}$, and A.B.M. Shahed ${ }^{3}$ \\ ${ }^{1}$ Dept. of Farm Power and Machinery, Faculty of Agricultural Engineering and Technology, Khulna Agricultural University, \\ Khulna-9100, Bangladesh; ${ }^{2}$ Farm Machinery and Postharvest Technology Division, Bangladesh Rice Research Institute, \\ Gazipur-1701, Bangladesh; ${ }^{3}$ Dept. of Farm Power and Machinery, Faculty of Agricultural Engineering and Technology, \\ Sylhet Agricultural University, Sylhet-3100, Bangladesh. \\ *Correspondence: rashed.fpm@ @au.ac.bd (Dr. Muhammad Rashed Al Mamun, Professor, Dept. of Farm Power and Machinery, \\ Faculty of Agricultural Engineering and Technology, Sylhet Agricultural University, Sylhet-3100, Bangladesh).
}

\begin{abstract}
Cold mitigation mechanism at seedling stage is a primary requirement during Boro season as seedlings are raised during months of November and December. This study was conducted at the Sylhet Agricultural University's Agricultural and Biosystem Engineering lab in Sylhet during the 2018-19 academic year. The focus of this study is to mitigate the biotic and abiotic effect on germination and mat-type seedling growing during Boro season. A two-factor design with three replications was used in the experiment. As abiotic stress control factors, six treatments were taken under two different thicknesses $(0.04 \mathrm{~mm}$ and $0.08 \mathrm{~mm})$ of white polythene sheds that covered day time only (12 hours) and day and night time ( 24 hours). Along with that two fungicides (Atavo and Autostin) and MoP fertilizer were used to control biotic stress on young seedlings raised in a plastic tray. Agronomical characteristics were measured in two intervals (after 15 and 30 days). The combined effect of $0.08 \mathrm{~mm}$ thick polythene shed and MoP treatment showed the highest value for seedling height $(167.3 \mathrm{~mm})$, a number of leafs $(4)$, leaf length $(99.8 \mathrm{~mm})$, stem length $(73.5 \mathrm{~mm})$ and seedling density $\left(18 / \mathrm{cm}^{2}\right)$. Fungal infection was found lowest in $0.08 \mathrm{~mm}$ polythene covered day, and night time. Seedling raised plastic trays are much more effective than the conventional way in terms of germination and quality. So, $0.08 \mathrm{~mm}$ thick white polythene was recommended as a covering mechanism and MoP as a treating mechanism for seedling rising in cold weather of Sylhet region.
\end{abstract}

Keywords: Rice transplanted, Temperature, Germination, Covering mechanism, and Agronomic characteristics.

\section{INTRODUCTION:}

Mechanical rice transplanters have gained a lot of popularity in Bangladesh these days. Due to a labor shortage, mechanical rice seedling transplanting is gaining popularity. Mechanical rice transplantation is the most promising method since it saves labor, ensures timely transplanting, and achieves optimal plant density, all of which lead to excellent yield (Kumar et al., 2015). When compared to manual transplantation, mechanical transplanting saved 66 percent of the cost UniversePG I www.universepg.com of transplanting and took just $7 \%$ of the time (Sharma et al., 2002). Each plant has its own set of temperature requirements, which must be met in order for the plant to grow and develop properly. The critical minimum temperature for shoot elongation in rice is $7^{\circ} \mathrm{C}$ to $16^{\circ} \mathrm{C}$, while the critical minimum temperature for root elongation is $12^{\circ} \mathrm{C}$ to $16^{\circ} \mathrm{C}$ (Yoshida, 1981).

Cold stress has a negative impact on rice (Oryza sativa L.) growth and production, as well as its geographic 
dispersion. Identifying cold stress-induced physiological changes and improving rice breeding for cold tolerance (Zhang et al., 2014). Cold mitigation mechanism at seedling stage is a primary requirement as seedlings are raised during the cold months of November and December during Boro season. To overcome the current seedling raising issue for mechanical transplanting, effective strategies that promote low-temperature stress tolerance (abiotic) during germination and early seedling stages are of great importance to raise mat type seedling of rice during Boro season.

An effective technique for resisting adverse effect of cold weather on rice seedling growth during Boro season is to use polythene shed to protect seedlings from low temperature. Inside temperatures of polythene sheds were recorded at 4 times viz. $6.00 \mathrm{am}, 12.00 \mathrm{pm}$, $6.00 \mathrm{pm}$ and $10.00 \mathrm{pm}$ throughout 21 days of seedling raising period. Plant quality at other treatments was found significantly better than traditional seedling rising without shed (Kamruzzaman et al., 2014). The seed-mats could be prepared in the winter and preserved until the spring seedling-raising period. Seedling mats for the rice transplanted could be created using seed-mats instead of nursery boxes, which take up storage space and require a lot of labor (Hiroyuki et al., 2008). Seeding growing media in the seedling tray has a significant impact on height, leaf number, and thickness of stem. For quality seedlings, soil and manure type, as well as manure mixture ratio to soil and different covering media, are important factors (Shahed et al., 2020).

In order to raise high-quality seedlings that meet agronomical requirements, thereby promoting the use of mechanical translators in Bangladesh. During the irrigated dry season, a study was performed under the proposed research plan with the following objectives:

○ To develop a mat type seedling rising protocol for Boro season.

- To identify suitable grade of polythene to combat low temperature during seedling rising in Boro season.

- To evaluate the seedling quality raised under different biotic and abiotic treatments combinations.

\section{MATERIALS AND METHODS:}

During the Boro season of 2018-19, this study was carried out at the Sylhet Agricultural University's Agricultural and Biosystem Engineering lab (from 12 December 2018 to 11 January 2019).

\section{Climatic condition of study area}

Sylhet's climate is mainly tropical. From April to October, the rainy season is hot and humid, with heavy showers and thunderstorms virtually every day. The rainy season lasts from April to October and is extremely hot and humid, with heavy showers and thunderstorms virtually every day, whereas the brief dry season lasts from November to February and is extremeely warm and clear. Between May and September, about $80 \%$ of the annual average rainfall of 4,200 millimeters (170 in) falls (Wikipedia). During the study period December-January temperature was cold and misty.

\section{Ambient temperature and relative humidity}

Temperature is an important factor for the growth of rice seedling raised in plastic tray. Ambient temperature during seedling raising period is presented in Fig 1.

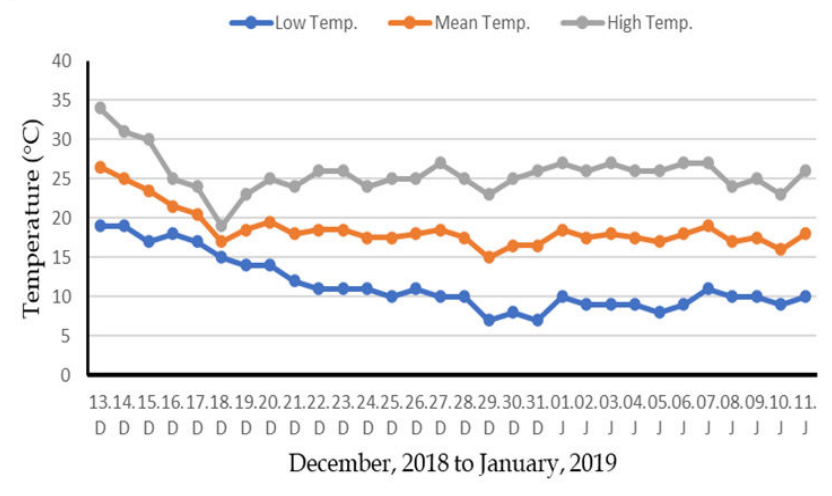

Fig 1: Ambient temperature during study period.

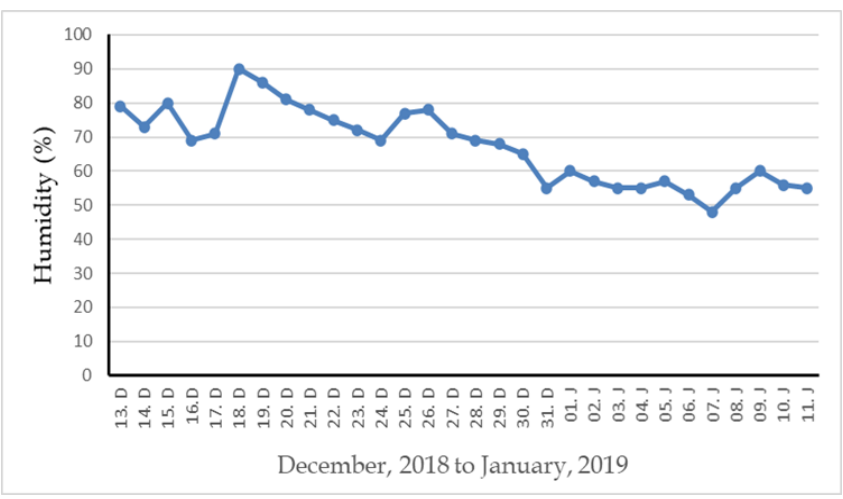

Fig 2: Ambient air humidity during study period. 
The highest atmospheric temperature was observed $34^{\circ}$ $\mathrm{C}$ and the lowest temperature was $7^{\circ} \mathrm{C}$ during seedling growing period. Ambient humidity showed in Fig 2 was collected from local weather station for observation purpose.

\section{General Information}

\section{Treatments and design}

To manage biotic and abiotic stress on mat type rice seedlings, the experiment used a two-factor design with three repetitions. The main factor was the covering mechanism (whole time, night time only and uncovered) of the seedling tray by white polythene of different thickness $(0.04$ and $0.08 \mathrm{~mm})$ available in the markets while treating seeds as well as spray on young seedling immediate after immergence considered as sub-factor of the study. Main and sub-factors were considered to observe the effect of covering and treating mechanism on abiotic and biotic stress, respectively. The treatments arrangement is mentioned as above. Seeds were treated using the fungicide $\left(F_{1}\right.$ and $F_{2}$ ) before 10-12 hours of germination. Fungicide was spread on young seedling immediate after seedling emergence $\left(F_{3}\right.$ to $\left.F_{4}\right)$. Other management was same for all treatments. The agronomic and mechanical parameters of the raised seedling were assessed at 15 and 30 days after sowing. Sprinkler irrigation was used to irrigate regularly throughout the seedling growing period.

Table 1: General information during study period.

\begin{tabular}{|c|c|c|c|c|c|c|}
\hline $\begin{array}{c}\text { Growing } \\
\text { Season }\end{array}$ & Variety & $\begin{array}{c}\text { Weight of grain, } \mathrm{g} \\
(1000)\end{array}$ & Sowing date & $\begin{array}{c}\text { Germination } \\
(\%)\end{array}$ & Soil characteristics & Growing period \\
\hline $\begin{array}{c}\text { Boro/ } \\
2018-19\end{array}$ & $\begin{array}{c}\text { BRRI } \\
\text { dhan28 }\end{array}$ & 23.10 & 12 Dec, 2018 & 88 & $\begin{array}{c}\text { sandy clay loam } \\
(\text { Sand } 62.2 \%, \text { silt } 15.05 \% \\
\text { and clay } 26.08 \%)\end{array}$ & $\begin{array}{r}12 \text { Dec, } 2018 \\
\text { to Jan, } 2019\end{array}$ \\
\hline
\end{tabular}

Table 2: Treatment arrangement.

\begin{tabular}{|c|c|}
\hline Main Factor A to control abiotic stress & Factor B to control biotic stress \\
\hline $\mathrm{P}_{1}=$ Covering by $0.04 \mathrm{~mm}$ thickness polythene (day and night time) & $\mathrm{F}_{1}=$ Fungicide-1 (seed treatment) \\
$\mathrm{P}_{2}=$ Covering by $0.04 \mathrm{~mm}$ thickness polythene (night time only) & $\mathrm{F}_{2}=$ Fungicide- 2 (seed treatment) \\
$\mathrm{P}_{3}=$ Covering by $0.08 \mathrm{~mm}$ thickness polythene (day and night time) & $\mathrm{F}_{3}=$ Fungicide- 1 (spraying on seedling) \\
$\mathrm{P}_{4}=$ Covering by $0.08 \mathrm{~mm}$ thickness polythene (night time only) and & $\mathrm{F}_{4}=$ Fungicide- (spraying on seedling) \\
$\mathrm{P}_{5}=$ Control (uncovered) & $\mathrm{F}_{5}=\mathrm{MOP}(8-10 \mathrm{~g} /$ tray) \\
& $\mathrm{F}_{6}=$ control (no fungicide). \\
\hline
\end{tabular}

Table 3: Description of the fungicide applied as biotic stress control agent.

\begin{tabular}{|c|c|c|c|c|}
\hline Fungicide Treatments & Brand name & Group & Active ingredient (AI) & Recommended dose \\
\hline $\mathrm{F}_{1}$ & $\begin{array}{c}\text { Atavo 75 WDG(Water } \\
\text { Dispersible Granule) }\end{array}$ & Carbendazim & $\begin{array}{c}\text { Imidacloprid 250 gm+ } \\
\text { Carbendazim 250 gm + thriam } \\
250 \text { per kg }\end{array}$ & $5 \%$ per 10-liter water \\
\hline $\mathrm{F}_{2}$ & Autostin 50 WDG & Carbendazim & Carbendazim 500 per kg & $2-3 \mathrm{~g}$. per liter of water \\
\hline
\end{tabular}

\section{Data collection}

The agronomic features of seedling as height, number of leaves, leaf length, stem length, and stem thickness were measured in two intervals (15 and 30 days) during growing period. The seedling density was determined after 30 days of planting. The seedling height, number of leaves, leaf length, stem length, and stem thickness were measured in millimeter $(\mathrm{mm})$ with the help of digital slide calipers. Nine plants from each replication were randomly picked from the collar UniversePG I www.universepg.com region to the tip of the seedling and the mean height was computed for analysis. The number of leaves on randomly selected nine plants were counted in both intervals (15 and 30 days). Identical plants were used to measure leaf length and stem thickness at 15 and 30 after seeding. A $100 \times 100 \mathrm{~mm}^{2}$ metal sheet box was used to calculate the seeding density of each tray. Using the Statistix 10 application, data was analyzed as a 2-way factorial design (factor $\mathrm{A} x$ factor $\mathrm{B}$ ). 


\section{RESULTS:}

\section{Inside temperature of the polythene shed}

For protecting the seedling from low temperature, seedling trays were coved by two different thicknesses $(0.04$ and $0.08 \mathrm{~mm})$ of white polythene sheet.

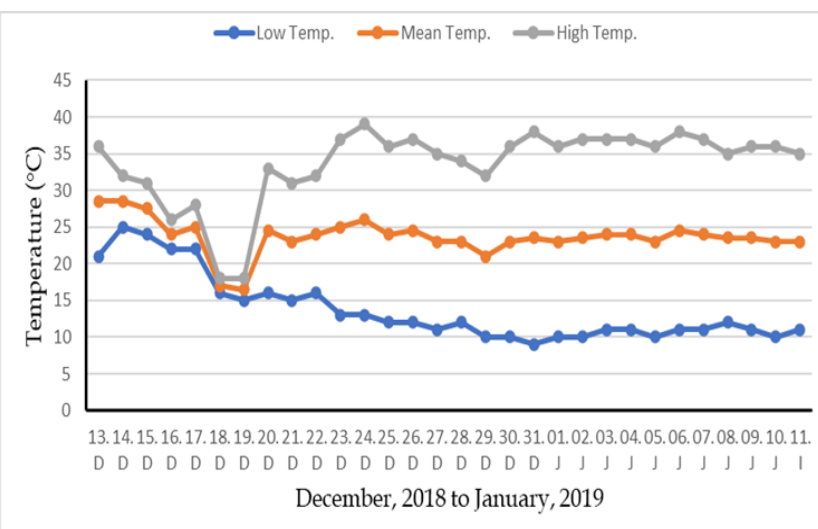

Fig 3: Inside temperature of 4 grade $(0.04 \mathrm{~mm}$ thickness) polythene

Inside temperature of the two different thickness of polythene shed is provided in Fig 3 and 4. As for abiotic stress control, the seedling trays which are covered by polythene $0.08 \mathrm{~mm}$ thickness showed significantly better performance than uncovered trays.
Fungal infection and seedling density were high in covered treys than uncovered treys.

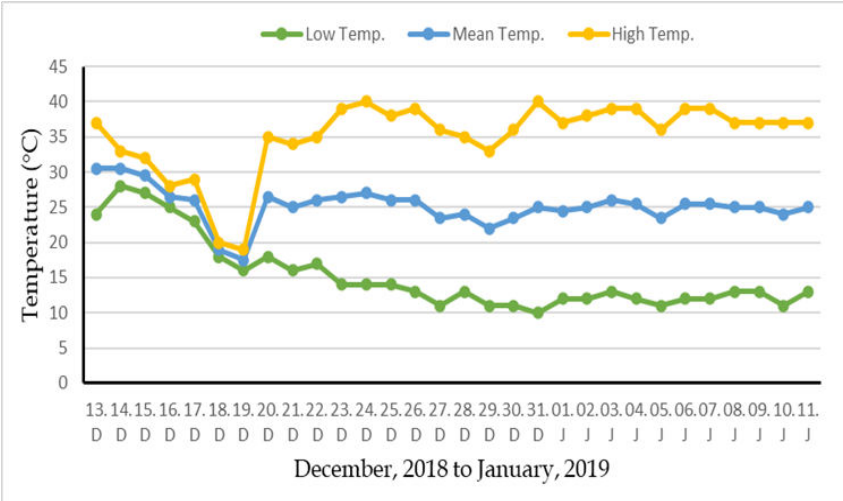

Fig 4: Inside temperature 8 grade (0.08 $\mathrm{mm}$ thickness) polythene

\section{Seedling height}

\section{Seedling height after 15 days}

At 15 days after planting, the interaction effect of abiotic stress factors (mode and method of covering) and biotic stress factors (seed and seedling treatment) had not significant effect on seedling height, although the single effects of abiotic stress factor and biotic stress factor showed opposite (Table 4).

Table 4: Effect of abiotic and biotic stress control factors on height of seedling at 15 days after sowing.

\begin{tabular}{|c|c|c|c|c|c|c|}
\hline \multirow{2}{*}{$\begin{array}{l}\text { Biotic stress control } \\
\text { factors (Seeds and } \\
\text { seedling treatment) }\end{array}$} & \multicolumn{5}{|c|}{ Abiotic stress control factors (mode and method of covering) } & \multirow[t]{2}{*}{ Mean } \\
\hline & $\begin{array}{c}\mathrm{P}_{1} \\
\text { day and night time }\end{array}$ & $\begin{array}{c}\mathbf{P}_{2} \\
\text { night time }\end{array}$ & $\begin{array}{c}\mathrm{P}_{3} \\
\text { day and night time }\end{array}$ & $\begin{array}{c}\mathrm{P}_{4} \\
\text { night time }\end{array}$ & $\begin{array}{c}\mathbf{P}_{5} \\
\text { uncovered }\end{array}$ & \\
\hline $\mathrm{F}_{1}$ & 98.8 & 123.4 & 113.7 & 131.4 & 88.9 & 111.2 \\
\hline $\mathrm{F}_{2}$ & 114.6 & 134.6 & 114.1 & 156.8 & 92.6 & 122.5 \\
\hline $\mathrm{F}_{3}$ & 117.1 & 117.7 & 105.8 & 156.0 & 95.5 & 118.4 \\
\hline $\mathrm{F}_{4}$ & 119.0 & 111 & 109.8 & 143.1 & 96.4 & 115.9 \\
\hline $\mathrm{F}_{5}$ & 118.3 & 145.1 & 125.2 & 167.3 & 105.5 & 132.3 \\
\hline $\mathrm{F}_{6}$ & 124.1 & 114.6 & 109.9 & 116.1 & 103.3 & 113.6 \\
\hline Mean & 115.3 & 124.4 & 113 & 145.1 & 97.0 & \\
\hline$\%$ of $\mathrm{cv}$ & \multicolumn{6}{|c|}{12.36} \\
\hline LoS & \multicolumn{6}{|c|}{$\mathrm{A}=*, \mathrm{~B}=*$ and $\mathrm{A} \times \mathrm{B}=\mathrm{NS}$} \\
\hline $\operatorname{LSD}_{0.05}$ & & & $=9.81$ and $\mathrm{B}=10.75$ & & & \\
\hline
\end{tabular}

Note: NS-*-significant at $1 \%$, LoS-Level of significance, Not significant, **-significant at $5 \%$

When seedling trays were coated for 24 hours with both thicknesses of polythene shed and treated with MoP spray. Seedling height was astounding. Both seed and seedling treatments yielded desired results in the case of $0.008 \mathrm{~mm}$ polythene shed. On the contrary 24 hours covered and uncovered treys shows poor quality of seedling when covered treys were treated with two different fungicide and MoP (Table 4).

UniversePG I www.universepg.com

\section{Seedling height after 30 days}

The interaction effect of abiotic (mode and method of covering) and biotic stress control factors (seeds and seedling treatment), as well as the single effects of abiotic stress factor and biotic stress factor, had a substantial impact on seedling height (Table 5). With $0.08 \mathrm{~mm}$ thickness polythene shed covered 24 hours (day and night) and treated with MOP spray, seedling 
height showed remarkable value after 30 days. Some treatments, on the other hand, did not produce the desired results.

\section{Number of Leaf}

\section{Number of leaves after 15 days}

The two-way interaction of abiotic (covering mode and method) and biotic stress control variables (seeds and seedling treatment) on leaf number was significantly different from the single effect of abiotic stress factor.
While the biotic stress factor has no effect on the number of leaves per plant, (Table 6). Number of leaves per plant was notable almost all treatment, except uncovered trays. But significantly higher value was observed when $0.04 \mathrm{~mm}$ thickness polythene shed was used to cover the seedling tray only day times and 0.08 $\mathrm{mm}$ thickness of polythene as well. Seedling treated with fungicide 1 (Atavo) showed better performance than other treatments.

Table 5: Effect of abiotic and biotic stress control factors on seedling height at 30 days after seeds sowing.

\begin{tabular}{|c|c|c|c|c|c|c|}
\hline \multirow{2}{*}{$\begin{array}{l}\text { Biotic stress control } \\
\text { factors (Seeds and } \\
\text { seedling treatment) }\end{array}$} & \multicolumn{5}{|c|}{ Abiotic stress control factors (mode and method of covering) } & \multirow[t]{2}{*}{ Mean } \\
\hline & $\begin{array}{c}P_{1} \\
\text { day and night time }\end{array}$ & $\begin{array}{c}\mathbf{P}_{2} \\
\text { night time only }\end{array}$ & \begin{tabular}{|c|}
$\mathbf{P}_{3}$ \\
day and night time
\end{tabular} & $\begin{array}{c}\mathbf{P}_{4} \\
\text { night time only }\end{array}$ & $\begin{array}{c}\mathbf{P}_{5} \\
\text { uncovered }\end{array}$ & \\
\hline $\mathrm{F}_{1}$ & 134.91 & 140.55 & 123.11 & 142.87 & 90.24 & 126.34 \\
\hline $\mathrm{F}_{2}$ & 115.96 & 162.36 & 112.42 & 147.05 & 94.77 & 126.51 \\
\hline $\mathrm{F}_{3}$ & 112.08 & 152.66 & 117.16 & 158.8 & 85.61 & 125.27 \\
\hline $\mathrm{F}_{4}$ & 126.79 & 148.18 & 114.33 & 155.96 & 95.55 & 128.16 \\
\hline $\mathrm{F}_{5}$ & 143.27 & 162.01 & 122.66 & 196.63 & 103.87 & 145.69 \\
\hline $\mathrm{F}_{6}$ & 129.64 & 128.92 & 99.4 & 151.68 & 92.79 & 120.49 \\
\hline Mean & 127.11 & 149.12 & 114.85 & 158.84 & 93.81 & \\
\hline$\%$ of cv & \multicolumn{6}{|c|}{9.22} \\
\hline LoS & \multicolumn{6}{|c|}{$\mathrm{A}=*, \mathrm{~B}=*$ and $\mathrm{A} \times \mathrm{B}=*$} \\
\hline $\operatorname{LSD}_{0.05}$ & \multicolumn{6}{|c|}{$\mathrm{A}=7.9161, \mathrm{~B}=8.6716$ and $\mathrm{A} \times \mathrm{B}=19.39$} \\
\hline
\end{tabular}

Note: NS- *-significant at $1 \%$, LoS-Level of significance, Not significant, **-significant at $5 \%$

Table 6: Effect of abiotic and biotic stress control factors on number of leaves per plant of seedlings at 15 days after seeds sowing.

\begin{tabular}{|c|c|c|c|c|c|c|}
\hline \multirow{2}{*}{$\begin{array}{l}\text { Biotic stress control } \\
\text { factors (Seeds and } \\
\text { seedling treatment) }\end{array}$} & \multicolumn{5}{|c|}{ Abiotic stress control factors (mode and method of covering) } & \multirow[t]{2}{*}{ Mean } \\
\hline & $\begin{array}{c}P_{1} \\
\text { day and night time }\end{array}$ & $\begin{array}{c}\mathbf{P}_{2} \\
\text { night time only }\end{array}$ & $\begin{array}{c}\mathrm{P}_{3} \\
\text { day and night time }\end{array}$ & $\begin{array}{c}\mathbf{P}_{4} \\
\text { night time only }\end{array}$ & $\begin{array}{c}\mathbf{P}_{5} \\
\text { uncovered }\end{array}$ & \\
\hline $\mathrm{F}_{1}$ & 3 & 2.6 & 3 & 3 & 2.6 & 2.8 \\
\hline $\mathrm{F}_{2}$ & 3 & 2 & 2.3 & 3 & 2.6 & 2.6 \\
\hline $\mathrm{F}_{3}$ & 3 & 3 & 3 & 2.3 & 2.3 & 2.7 \\
\hline $\mathrm{F}_{4}$ & 2.6 & 3 & 2 & 3 & 2 & 2.5 \\
\hline $\mathrm{F}_{5}$ & 2.6 & 2.6 & 2.3 & 3 & 2 & 2.5 \\
\hline $\mathrm{F}_{6}$ & 2.6 & 3 & 2.3 & 2.6 & 2 & 2.5 \\
\hline Mean & 2.8 & 2.7 & 2.5 & 2.8 & 2.2 & \\
\hline$\%$ of $\mathrm{cv}$ & \multicolumn{6}{|c|}{13.93} \\
\hline LoS & \multicolumn{6}{|c|}{$\mathrm{A}=*, \mathrm{~B}=\mathrm{NS}$ and $\mathrm{A} \times \mathrm{B}=*$} \\
\hline $\mathrm{LSD}_{0.05}$ & \multicolumn{6}{|c|}{$\mathrm{A}=0.24$ and $\mathrm{A} \times \mathrm{B}=0.59$} \\
\hline
\end{tabular}

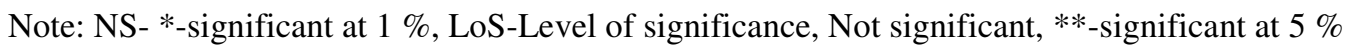

\section{Number of leaves after 30 days}

Along with the single effect of biotic stress factor, the two-way interaction of abiotic stress control factor (mode and method of covering) and biotic stress control factor (seeds and seedling treatment) had no significant effect on leaf number. Although the single effect of the abiotic stress control factor had a significant effect on the number of leaves, the combined effect of the abiotic stress control factor had a significant effect on the number of (Table 7). When seedlings were covered 24 hours by $0.04 \mathrm{~mm}$ thickness polythene and spray by fungicide 1(Atavo) number of leafs per plant 
showed significant result. Others covering method also showed desired performance except uncovered trays.

\section{Leaf Length}

\section{Leaf length after 15 days}

Abiotic stress factor (mode and method of covering) and biotic stress factor (seeds and seedling treatment) showed insignificant effect on leaf length combined even though the single effect of abiotic stress and biotic stress factors showed significant effect (Table 8). Leaf length was higher when seedling was covered 24 hours by $0.08 \mathrm{~mm}$ thickness polythene with fungicide 2 (Autostin) either sprayed or pretreated before sowing. The uncovered seedling showed poor performance in all treatment compare to other covering method.

Table 7: Effect of abiotic and biotic stress control factors on number of leaf per plant of seedlings at 30 days after sowing.

\begin{tabular}{|c|c|c|c|c|c|c|}
\hline \multirow{2}{*}{$\begin{array}{l}\text { Biotic stress control } \\
\text { factors (Seeds and } \\
\text { seedling treatment) }\end{array}$} & \multicolumn{5}{|c|}{ Abiotic stress control factor (mode and method of covering) } & \multirow[t]{2}{*}{ Mean } \\
\hline & $\begin{array}{c}P_{1} \\
\text { day and night time }\end{array}$ & $\begin{array}{c}\mathbf{P}_{2} \\
\text { night time only }\end{array}$ & \begin{tabular}{|c|}
$\mathbf{P}_{3}$ \\
day and night time
\end{tabular} & \begin{tabular}{|c|}
$\mathbf{P}_{4}$ \\
night time only
\end{tabular} & $\mid \begin{array}{c}\mathbf{P}_{5} \\
\text { uncovered }\end{array}$ & \\
\hline $\mathrm{F}_{1}$ & 3.6 & 3.6 & 4 & 3.3 & 4 & 3.7 \\
\hline $\mathrm{F}_{2}$ & 3.3 & 3.6 & 4 & 4 & 4 & 3.8 \\
\hline $\mathrm{F}_{3}$ & 3.3 & 4 & 4 & 4 & 4 & 3.8 \\
\hline $\mathrm{F}_{4}$ & 3.6 & 4 & 4 & 3.3 & 3.6 & 3.7 \\
\hline $\mathrm{F}_{5}$ & 3 & 4 & 4 & 4 & 4 & 3.8 \\
\hline $\mathrm{F}_{6}$ & 3.3 & 3.6 & 3.3 & 4 & 3.3 & 3.5 \\
\hline Mean & 3.3 & 3.8 & 3.8 & 3.7 & 3.8 & \\
\hline$\%$ of $\mathrm{cv}$ & \multicolumn{6}{|c|}{10.15} \\
\hline LoS & \multicolumn{6}{|c|}{$\mathrm{A}=*, \mathrm{~B}=\mathrm{NS}$ and $\mathrm{A} \times \mathrm{B}=\mathrm{NS}$} \\
\hline $\operatorname{LSD}_{0.05}$ & \multicolumn{6}{|c|}{$A=0.2536$} \\
\hline
\end{tabular}

Note: NS- *-significant at $1 \%$, LoS-Level of significance, Not significant, $* *$-significant at $5 \%$

Table 8: Effect of abiotic and biotic stress factor on leaf length at 15 days after seeds sowing.

\begin{tabular}{|c|c|c|c|c|c|c|}
\hline \multirow{2}{*}{$\begin{array}{l}\text { Biotic stress control } \\
\text { factors (Seeds and } \\
\text { seedling treatment) }\end{array}$} & \multicolumn{5}{|c|}{ Abiotic stress control factors (mode and method of covering) } & \multirow[t]{2}{*}{ Mean } \\
\hline & \begin{tabular}{|c|}
$P_{1}$ \\
day and night time
\end{tabular} & $\begin{array}{c}\mathbf{P}_{2} \\
\text { night time only }\end{array}$ & $\frac{\mathbf{P}_{3}}{\text { day and night time }}$ & \begin{tabular}{|c|}
$\mathbf{P}_{4}$ \\
night time only
\end{tabular} & $\begin{array}{c}P_{5} \\
\text { uncovered }\end{array}$ & \\
\hline $\mathrm{F}_{1}$ & 64.0 & 73.4 & 67.8 & 76.6 & 51.9 & 66.8 \\
\hline $\mathrm{F}_{2}$ & 68.6 & 88.3 & 70.8 & 99.8 & 60.0 & 77.5 \\
\hline $\mathrm{F}_{3}$ & 72.4 & 65.6 & 67.0 & 97.5 & 60.0 & 72.5 \\
\hline $\mathrm{F}_{4}$ & 71.4 & 66.6 & 68.9 & 83.1 & 63.4 & 70.7 \\
\hline $\mathrm{F}_{5}$ & 75.2 & 86. & 77.5 & 93.7 & 71.4 & 80.8 \\
\hline $\mathrm{F}_{6}$ & 76.7 & 64.4 & 70.5 & 72.1 & 69.7 & 70.7 \\
\hline Mean & 71.4 & 74.1 & 70.4 & 87.1 & 62.7 & \\
\hline$\%$ of $\mathrm{cv}$ & \multicolumn{6}{|c|}{16.52} \\
\hline LoS & \multicolumn{6}{|c|}{$\mathrm{A}=*, \mathrm{~B}=* *$ and $\mathrm{A} \times \mathrm{B}=\mathrm{NS}$} \\
\hline $\mathrm{LSD}_{0.05}$ & \multicolumn{6}{|c|}{$\mathrm{A}=8.06$ and $\mathrm{B}=8.83$} \\
\hline
\end{tabular}

Note: NS- *-significant at $1 \%$, LoS-Level of significance, Not significant, $* *$-significant at $5 \%$

\section{Leaf length after 30 days}

Along with the single effect of abiotic stress and biotic stress control factors, a two-way interaction of abiotic stress factor (mode and method of covering) and biotic stress control factor (seeds and seedling treatment) had a significant effect on leaf length (Table 9). When seedlings were covered 24 hours by $0.08 \mathrm{~mm}$ thickness polythene and sprayed MoP the leaf length showed significantly higher value than all other treatment. On the other hand, uncovered seedling showed significantly lower leaf length.

\section{Stem Length}

\section{Stem length after 15 days}

Effect of abiotic stress factor (mode and method of covering) and biotic stress control (seeds and seedling treatment) showed significant effect on stem length 
combined as were the single effect of abiotic and biotic stress control factors (Table 10). Stem length was significantly higher when seedling was covered 24 hours by $0.08 \mathrm{~mm}$ thickness polythene shed and treated by MoP spray. Uncovered seedling showed poor performance in stem length.

Table 9: Effect of abiotic and biotic stress control factors on leaf length at 30 days after seeds sowing.

\begin{tabular}{|c|c|c|c|c|c|c|}
\hline \multirow{2}{*}{$\begin{array}{l}\text { Biotic stress control } \\
\text { factors (Seeds and } \\
\text { seedling treatment) }\end{array}$} & \multicolumn{5}{|c|}{ Abiotic stress control factors (mode and method of covering) } & \multirow[t]{2}{*}{ Mean } \\
\hline & \begin{tabular}{|c|}
$P_{1}$ \\
day and night time
\end{tabular} & \begin{tabular}{|c|}
$\mathbf{P}_{2}$ \\
night time only
\end{tabular} & $\begin{array}{c}\mathbf{P}_{3} \\
\text { day and night time }\end{array}$ & \begin{tabular}{c|}
$\mathbf{P}_{4}$ \\
night time only
\end{tabular} & $\begin{array}{c}P_{5} \\
\text { uncovered }\end{array}$ & \\
\hline $\mathrm{F}_{1}$ & \begin{tabular}{|l|l}
83.9 & \\
\end{tabular} & 87.4 & \begin{tabular}{|l|l}
74.8 & \\
\end{tabular} & 89.7 & 58.0 & 78.8 \\
\hline $\mathrm{F}_{2}$ & 74.7 & 99.4 & 68.4 & 91.3 & 61.7 & 79.1 \\
\hline $\mathrm{F}_{3}$ & 68.9 & 93.1 & 78.7 & 101.7 & 51.7 & 78.8 \\
\hline $\mathrm{F}_{4}$ & 80 & 91.2 & 73.5 & 94.3 & 64.9 & 80.8 \\
\hline $\mathrm{F}_{5}$ & 91.2 & 99.7 & 75.3 & 125.2 & 69.9 & 92.3 \\
\hline $\mathrm{F}_{6}$ & 81.6 & 79.4 & 63.5 & 96.2 & 61.8 & 76.5 \\
\hline Mean & 80.0 & 91.7 & 72.4 & 99.7 & 61.3 & \\
\hline$\%$ of cv & \multicolumn{6}{|c|}{9.7} \\
\hline LoS & \multicolumn{6}{|c|}{$\mathrm{A}=*, \mathrm{~B}=*$ and $\mathrm{A} \times \mathrm{B}=*$} \\
\hline $\mathrm{LSD}_{0.05}$ & \multicolumn{6}{|c|}{$\mathrm{A}=5.24, \mathrm{~B}=5.74$ and $\mathrm{A} \times \mathrm{B}=12.85$} \\
\hline
\end{tabular}

Note: NS- *-significant at $1 \%$, LoS-Level of significance, Not significant, $* *$-significant at $5 \%$

Table 10: Effect of abiotic and biotic stress factor on stem length at 15 days after seeds sowing.

\begin{tabular}{|c|c|c|c|c|c|c|}
\hline \multirow{2}{*}{$\begin{array}{l}\text { Biotic stress control } \\
\text { factors (Seeds and } \\
\text { seedling treatment) }\end{array}$} & \multicolumn{5}{|c|}{ Abiotic stress control factors (mode and method of covering) } & \multirow[b]{2}{*}{ Mean } \\
\hline & $\begin{array}{c}P_{1} \\
\text { day and night }\end{array}$ & $\begin{array}{c}\mathbf{P}_{2} \\
\text { night time only }\end{array}$ & $\begin{array}{c}P_{3} \\
\text { day and night }\end{array}$ & \begin{tabular}{|c|}
$\mathbf{P}_{4}$ \\
night time only
\end{tabular} & $\begin{array}{c}\mathbf{P}_{5} \\
\text { uncovered }\end{array}$ & \\
\hline $\mathrm{F}_{1}$ & 34.7 & 49.9 & 45. & 54.7 & 36.9 & 44.4 \\
\hline $\mathrm{F}_{2}$ & 45.9 & 46.2 & 43.2 & 57.0 & 32.5 & 45.0 \\
\hline $\mathrm{F}_{3}$ & 44.7 & 52.0 & 38.8 & 58.5 & 35.5 & 45.9 \\
\hline $\mathrm{F}_{4}$ & 47.5 & 44.3 & 40.9 & 59.9 & 32. & 45.1 \\
\hline $\mathrm{F}_{5}$ & 43.1 & 58.8 & 47.7 & 73.5 & 34.1 & 51.4 \\
\hline $\mathrm{F}_{6}$ & 47.4 & 50.2 & 39.3 & 44.0 & 33. & 42.9 \\
\hline Mean & $43.9 \mathrm{c}$ & $50.2 \mathrm{~b}$ & $42.6 \mathrm{c}$ & $57.9 \mathrm{a}$ & 34.2 & \\
\hline$\%$ of cv & \multicolumn{6}{|c|}{14.97} \\
\hline LoS & \multicolumn{6}{|c|}{$\mathrm{A}=*, \mathrm{~B}=* *$ and $\mathrm{A} \times \mathrm{B}=* *$} \\
\hline $\operatorname{LSD}_{0.05}$ & \multicolumn{6}{|c|}{$\mathrm{A}=4.57, \mathrm{~B}=5.01$ and $\mathrm{A} \times \mathrm{B}=11.21$} \\
\hline
\end{tabular}

Note: NS- *-significant at $1 \%$, LoS-Level of significance, Not significant, **-significant at $5 \%$

\section{Stem length after 30 days}

Interaction effect of abiotic stress factor (mode and method of covering) and biotic stress control (seeds and seedling treatment) did not show significant effect on stem length. Whereas the single effect of abiotic stress and biotic stress factor showed significant effect on stem length (Table 11). When seedlings were covered with $0.08 \mathrm{~mm}$ thick polythene shed for 24 hours and treated with MoP spray, stem length increased significantly. In every case, the unprotected seed-ling had a weak stem.

\section{Stem Thickness}

Stem thickness after 15 days

UniversePG I www.universepg.com
Along with the single impact of biotic stress control factor, abiotic (mode and method of covering) and biotic stress control factors (seeds and seedling treatment) had no significant impact on stem thickness. Despite the fact that the single effect of the abiotic stress control factor was significant (Table 12). Stem thickness was notable when the seedlings were covered only night time by $0.08 \mathrm{~mm}$ thickness of polythene and sprayed by fungicide 1 (Atavo).

\section{Stem thickness after 30 days}

Effect of abiotic stress control factor (mode and method of covering) and biotic stress factor (seed and seedling treatment) did not show significant effect on stem thickness along with the single effect of biotic 
stress control. Although the single effect of abiotic stress showed significant effect (Table 13). After 30 days uncovered seedlings showed significant perfor- mance in stem thickness when seed treated with fungicide 1 (Atavo).

Table 11: Effect of abiotic and biotic stress control factor on stem length at 30 days after seeds sowing.

\begin{tabular}{|c|c|c|c|c|c|c|}
\hline \multirow{2}{*}{$\begin{array}{l}\text { Biotic stress control } \\
\text { factors (Seeds and } \\
\text { seedling treatment) }\end{array}$} & \multicolumn{5}{|c|}{ Abiotic stress control factors (mode and method of covering) } & \multirow[t]{2}{*}{ Mean } \\
\hline & $\begin{array}{c}P_{1} \\
\text { day and night time }\end{array}$ & $\begin{array}{c}\mathbf{P}_{2} \\
\text { night time only }\end{array}$ & $\begin{array}{c}\mathbf{P}_{3} \\
\text { day and night time }\end{array}$ & $\begin{array}{c}\mathbf{P}_{4} \\
\text { night time only }\end{array}$ & $\mid \begin{array}{c}\mathbf{P}_{5} \\
\text { uncovered }\end{array}$ & \\
\hline $\mathrm{F}_{1}$ & 50.9 & 53.0 & 48.2 & 53.1 & 32.1 & 47.5 \\
\hline $\mathrm{F}_{2}$ & 41.2 & 62.9 & 43.9 & 55.6 & 33.0 & 47.3 \\
\hline $\mathrm{F}_{3}$ & 43.1 & 59.5 & 38.3 & 57.0 & 33.8 & 46.3 \\
\hline $\mathrm{F}_{4}$ & 46.7 & 56.9 & 40.7 & 61.5 & 30.6 & 47.3 \\
\hline $\mathrm{F}_{5}$ & 52.0 & 62.2 & 47.2 & 71.3 & 33.9 & 53.3 \\
\hline $\mathrm{F}_{6}$ & 47.9 & 49.4 & 35.8 & 55.3 & 30.8 & 43.9 \\
\hline Mean & 47.0 & 57.3 & 42.4 & 59.0 & 32.4 & \\
\hline$\%$ of $\mathrm{cv}$ & \multicolumn{6}{|c|}{12.02} \\
\hline LoS & \multicolumn{6}{|c|}{$\mathrm{A}=*, \mathrm{~B}=*$ and $\mathrm{A} \times \mathrm{B}=\mathrm{NS}$} \\
\hline $\operatorname{LSD}_{0.05}$ & \multicolumn{6}{|c|}{$\mathrm{A}=3.8216$ and $\mathrm{B}=4.1864$} \\
\hline
\end{tabular}

Note: NS- *-significant at $1 \%$, LoS-Level of significance, Not significant, $* *$-significant at $5 \%$

Table 12: Effect of abiotic and biotic stress control factors on stem thickness of seedlings at 15 days (mm) after seeds sowing.

\begin{tabular}{|c|c|c|c|c|c|c|}
\hline \multirow{2}{*}{$\begin{array}{l}\text { Biotic stress control } \\
\text { factors (Seeds and } \\
\text { seedling treatment) }\end{array}$} & \multicolumn{5}{|c|}{ Abiotic stress control factors (mode and method of covering) } & \multirow[t]{2}{*}{ Mean } \\
\hline & $\begin{array}{c}P_{1} \\
\text { day and night time }\end{array}$ & $\begin{array}{c}\mathbf{P}_{2} \\
\text { night time only }\end{array}$ & $\begin{array}{c}\mathrm{P}_{3} \\
\text { day and night time }\end{array}$ & $\begin{array}{c}\mathbf{P}_{4} \\
\text { night time only }\end{array}$ & \begin{tabular}{c|}
$P_{5}$ \\
uncovered
\end{tabular} & \\
\hline $\mathrm{F}_{1}$ & 0.89 & 0.97 & 1.01 & 0.96 & 0.98 & 0.96 \\
\hline $\mathrm{F}_{2}$ & 0.80 & 0.9 & 0.92 & 0.93 & 1.03 & 0.91 \\
\hline $\mathrm{F}_{3}$ & 0.89 & 0.82 & 1.1 & 0.80 & 0.96 & 0.91 \\
\hline $\mathrm{F}_{4}$ & 0.86 & 0.83 & 0.88 & 0.82 & 0.97 & 0.87 \\
\hline $\mathrm{F}_{5}$ & 0.96 & 0.91 & 0.9 & 0.91 & 0.92 & 0.92 \\
\hline $\mathrm{F}_{6}$ & 0.97 & 0.93 & 0.91 & 0.85 & 0.99 & 0.93 \\
\hline Mean & 0.89 & 0.89 & 0.95 & 0.88 & 0.97 & \\
\hline$\%$ of $\mathrm{cv}$ & \multicolumn{6}{|c|}{11.98} \\
\hline LoS & \multicolumn{6}{|c|}{$\mathrm{A}=* *, \mathrm{~B}=\mathrm{NS}$ and $\mathrm{A} \times \mathrm{B}=\mathrm{NS}$} \\
\hline $\operatorname{LSD}_{0.05}$ & \multicolumn{6}{|c|}{$A=0.073$} \\
\hline
\end{tabular}

Note: NS- *-significant at $1 \%$, LoS-Level of significance, Not significant, **-significant at $5 \%$

\section{Seedling density after 30 days}

The two-way interaction effect of abiotic and biotic stress control factors, as well as the single effect of biotic stress factor, had no major effect on seedling density. The single effect of abiotic stress, on the other hand, had a significant impact on seedling density (Table 14). Seedling density improved when seedlings were covered for 24 hours with $0.08 \mathrm{~mm}$ thick polythene shed and sprayed with MoP. In the case of seedlings in uncovered trays, growth was unsatisfactory.

Table 13: Effect of abiotic and biotic stress control factors on stem thickness ( $\mathrm{mm}$ ) at 30 days after seeds sowing.

\begin{tabular}{|c|c|c|c|c|c|c|}
\hline \multirow{2}{*}{$\begin{array}{c}\text { Biotic stress control } \\
\text { factor (Seeds and } \\
\text { seedling treatment) }\end{array}$} & \multicolumn{4}{|c|}{ Abiotic stress control factor (mode and method of covering) } \\
\cline { 2 - 7 } & $\begin{array}{c}\mathbf{P}_{\mathbf{1}} \\
\text { day and night time }\end{array}$ & $\begin{array}{c}\mathbf{P}_{\mathbf{2}} \\
\text { night time only }\end{array}$ & $\begin{array}{c}\mathbf{P}_{\mathbf{3}} \\
\text { day and night time }\end{array}$ & $\begin{array}{c}\mathbf{P}_{\mathbf{4}} \\
\text { night time only }\end{array}$ & $\begin{array}{c}\mathbf{P}_{\mathbf{5}} \\
\text { uncovered }\end{array}$ & \begin{tabular}{c} 
Mean \\
\hline $\mathrm{F}_{1}$
\end{tabular} \\
\hline $\mathrm{F}_{2}$ & 0.94 & 0.91 & 0.94 & 0.78 & 1.25 & 0.96 \\
\hline $\mathrm{F}_{3}$ & 0.91 & 0.94 & 0.87 & 0.97 & 0.95 & 0.89 \\
\hline
\end{tabular}




\begin{tabular}{|c|c|c|c|c|c|c|}
\hline $\mathrm{F}_{4}$ & 0.78 & 0.97 & 0.94 & 0.75 & 0.98 & 0.88 \\
\hline $\mathrm{F}_{5}$ & 0.91 & 0.87 & 0.86 & 0.86 & 1.0 & 0.90 \\
\hline $\mathrm{F}_{6}$ & 1.1 & 0.84 & 0.68 & 0.84 & 1.0 & 0.9 \\
\hline Mean & 0.93 & 0.89 & 0.83 & 0.82 & 1.0 & \\
\hline$\%$ of cv & \multicolumn{6}{|c|}{16.27} \\
\hline LoS & \multicolumn{6}{|c|}{$\mathrm{A}=*, \mathrm{~B}=\mathrm{NS}$ and $\mathrm{A} \times \mathrm{B}=\mathrm{NS}$} \\
\hline $\operatorname{LSD}_{0.05}$ & \multicolumn{6}{|c|}{$\mathrm{A}=0.098$} \\
\hline
\end{tabular}

Note: NS- *-significant at $1 \%$, LoS-Level of significance, Not significant, $* *$-significant at $5 \%$

Table 14: Interaction effect of abiotic and biotic stress control factors on seedling density at 30 days $\left(\mathrm{cm}^{2}\right)$ after sowing.

\begin{tabular}{|c|c|c|c|c|c|c|}
\hline \multirow{2}{*}{$\begin{array}{l}\text { Biotic stress control } \\
\text { factors (Seeds and } \\
\text { seedling treatment) }\end{array}$} & \multicolumn{5}{|c|}{ Abiotic stress control factors (mode and method of covering) } & \multirow[b]{2}{*}{ Mean } \\
\hline & $\begin{array}{c}P_{1} \\
\text { day and night time }\end{array}$ & $\begin{array}{c}\mathbf{P}_{2} \\
\text { night time }\end{array}$ & $\begin{array}{c}\mathbf{P}_{3} \\
\text { day and night time }\end{array}$ & $\begin{array}{c}\mathbf{P}_{4} \\
\text { night time }\end{array}$ & $\begin{array}{c}\mathbf{P}_{5} \\
\text { uncovered }\end{array}$ & \\
\hline $\mathrm{F}_{1}$ & 15 & 10 & 12 & 16.3 & 9.6 & 12.6 \\
\hline $\mathrm{F}_{2}$ & 14 & 11 & 13.6 & 16 & 13.6 & 13.6 \\
\hline $\mathrm{F}_{3}$ & 15.3 & 13 & 14.3 & 14.3 & 13.3 & 14.0 \\
\hline $\mathrm{F}_{4}$ & 14.6 & 12.3 & 15.3 & 15.6 & 9 & 13.4 \\
\hline $\mathrm{F}_{5}$ & 13 & 11.6 & 13.3 & 18 & 9.3 & 13.0 \\
\hline $\mathrm{F}_{6}$ & 12.6 & 11 & 11 & 12.6 & 12.6 & 12 \\
\hline Mean & 14.1 & 11.5 & 13.2 & 15.5 & 11.2 & \\
\hline$\%$ of $\mathrm{cv}$ & \multicolumn{6}{|c|}{18.98} \\
\hline LoS & \multicolumn{6}{|c|}{$\mathrm{A}=*, \mathrm{~B}=\mathrm{NS}$ and $\mathrm{A} \times \mathrm{B}=\mathrm{NS}$} \\
\hline $\operatorname{LSD}_{0.05}$ & \multicolumn{6}{|c|}{$\mathrm{A}=1.66$} \\
\hline
\end{tabular}

Note: NS- *-significant at $1 \%$, LoS-Level of significance, Not significant, **-significant at $5 \%$

\section{DISCUSSION:}

Temperature is a significant parameter for Boro rice seedling rising in this analysis. The highest temperature $\left(40^{\circ} \mathrm{C}\right)$ was reported within a $0.08 \mathrm{~mm}$ thick white polythene shed covered 24 hours. Meanwhile, at the lowest temperature $\left(9^{\circ} \mathrm{C}\right), 0.04 \mathrm{~mm}$ thick white polythene was shed which covered 12 hours. In another study the highest and the lowest temperatures were observed at $0.04 \mathrm{~mm}$ thick black polythene shed during day-night and $0.08 \mathrm{~mm}$ thick black polythene shed during day-night respectively (Kamruzzaman et al., 2014). As abiotic stress control factor white polythene shed with thickness of $0.04 \mathrm{~mm}$ and $0.08 \mathrm{~mm}$ were used in different time scale. The both thickness of white polythene was used to protect young seedlings from cold weather. Seedling height was observed highest when $0.08 \mathrm{~mm}$ thick polythene was used to cover the seedling trays for 24 hours (day and night). Moreover, seedlings covered with $0.08 \mathrm{~mm}$ thick polythene shed had the most leaves per plant, leaf length, stem length, and seedling density. Kamruzzaman et al. (2014) described in another study that $0.04 \mathrm{~mm}$ thick white polythene shed during day and night surpassed other treatments. The highest stem thickness was found where seedling trays were put in $0.04 \mathrm{~mm}$ thick white polythene shed during night. The lowest number of plants $\mathrm{cm}^{2}$ and plant height was found at traditional seedling rising without shed. Number of leaves plant-1 was the lowest in the tray which was kept under 0.04 $\mathrm{mm}$ thick blue polythene shed during day and night. The lowest length of leaf and stem thickness were found in tray which was kept under $0.04 \mathrm{~mm}$ thick blue polythene shed during night and $0.04 \mathrm{~mm}$ thick black polythene shed during day and night respectively. However, plant quality at other treatments was found significantly better than traditional seedling rising without shed. Seeding growing media in the seedling tray affects height of seedling, leaf number, stem thickness, and hence plant establishment with few missing hills. For producing high-quality seedlings, soil and manure kinds, as well as the ratio of manure mixture to soil and various covering media, are all considered as critical factors (Shahed et al., 2020). In case of biotic stress control factors the main aim of this study to use most common and economic fungicide so that farmers can easily manage to take care of their 
seedling. For treatment two fungicides was used for seed treatment on pre-germinated seeds and also for spraying on newly emerge seedlings. As fertilizer MoP was used. Most of the parameters such as Height of seed-ling, leaf length, stem length, stem thickness, and seed-ling density showed highest result

\section{CONCLUSION:}

The mechanical transplanting of rice is gaining popularity day by day. Mat type seed bed preparation is essential for mechanical transplanting of rice seedlings. Either a plastic tray or a polythene sheet can be used to make a mat-style seed bed. Agronomical superior seedlings are an important consideration in the large-scale use of rice transplanted. The current study was conducted using well-prepared dry sandy loom soil and sprouted seeds of BRRI dhan28. The aim of this study to find out appropriate control measure for seedling growth in cold weather of Boro season. Seedling covering mechanism by $0.08 \mathrm{~mm}$ thick polythene shed covered day and night time showed best result for all parameters. As sub factor seeds and seedling mechanism showed best result with both fungicide (Atavo and Autostin) when seeds are pretreated before sowing and MoP by spraying in young seedling. So, at last $0.08 \mathrm{~mm}$ thick white polythene was recommended for protecting seedling from cold in Boro season. As well as for biotic stress control factor fungicide Atavo, Autostin are recommended in pretreated seeds for preventing fungal infestation.

\section{ACKNOWLEDGEMENT:}

We appreciate the technical and financial assistance provided by the Bangladesh Rice Research Institute (BRRI) for this study. Also, many thanks to the lecturers and staff at Sylhet Agricultural University's Agricultural and Biosystem Engineering lab for their kind assistance.

\section{CONFLICTS OF INTEREST:}

There are no potential conflicts of interest for the authors to disclose. There are no financial interests to record, and all co-authors have seen and agreed with the contents of the work. We certify that the sub-mission is unique and that it is not currently under consideration by another publisher.

\section{REFERENCES:}

1) Hiroyuki K, Terauchi R. (2008) Regulation of expression of rice thaumatin-like protein: inducibility by elicitor requires promoter W-box elements. Plant cell reports. 27(9), 1521-8.

2) Kamruzzaman, M, Awal, MA, Hossen, MA, Paul, S. (2014). Protection of Seedling in Tray for Mechanical Rice Transplanting from Effect of Cold Weather Using Polythene Shed. Bangladesh J. of Progressive Science \& Technology, 12(1), 005-010, 2305-1809.

https://www.researchgate.net/publication/3082082 $\underline{98}$

3) Shahed, ABM, Tamanna, TA, and Mizanur, M. (2020). Impact of organic substance on growth attributes of mat type rice seedlings in the trays for machine transplanting. J. of Science, Technology and Environ. Inform., 10(01), 694-708.

4) Sharma, $S \mathrm{~N}$, Singh, P K, Srivastava, R K. (2002). Effect of tillage and mechanization on production potential of rice (Oryza sativa)-wheat (Triticum aestivum) crop-ping system. Indian J. of Agronomy, 47(3), 305-310.

https://www.indianjournals.com/ijor.aspx?target=ij or: $:$ ja $\&$ volume $=47 \&$ issue $=3 \&$ article $=001$

5) Sylhet, (2021). From Wikipedia, the free encyclopedia; last edited on 7 October 2021. https://en.wikipedia.org/wiki/Sylhet

6) Yoshida S. (1981). Fundamentals of rice crop science. Int. Rice Res. Inst.

7) Zhang, Q, Chen, Q, Wang, S, Hong, Y, Wang, Z. (2014). Rice and cold stress: methods for its evaluation and summary of cold tolerancerelated quantitative trait loci. Rice, 7(1), 1-12. http://www.thericejournal.com/content/7/1/24

Citation: Tamanna TA, Hossen MA, Al Mamun MR, and Shahed ABM. (2021). Mitigation of biotic and abiotic stresses in mat type seedlings raised for mechanical rice transplanter. Am. J. Pure Appl. Sci., 3(6), 125-134. https://doi.org/10.34104/ajpab.021.01250134 @) () 